\title{
The influence of technology and demand factors on firm size and industrial structure in the DRAM market - 1973-1988
}

\author{
David T. Methé \\ Corporate Strateg;, School of Business Admunstration, Unwersity of Michigan, Ann Arbor, Michigan 48109-1234, USA
}

Final version recerved November 1990

\begin{abstract}
The focus of this research is on the impact of the diffusion of innovations in integrated circuit technology on the market structure of that industry and the implications of firm strategy for both further innovation and market structure change. The study examines the effects of sustained product innovation over a fifteen-year-period in the DRAM segment of the integrated circuit industry. Assessments are made on first mover advantages, shape of the diffusion curve, and resource needs in a market characterized by an increasingly complex technology. Comparisons are made along the dimensions of number of firms in the market, continuity of the firms and market concentration.
\end{abstract}

\section{Introduction}

$\Lambda$ number of researchers have argued that technological change is the primary driving force behind the evolution of market structure $[8,33,34,38]$. Much of the research on the impact of sustained technological innovation on industry structure has taken either a macroeconomic approach [21a] or an historical case approach [38]. Building on this previous work, an evolutionary framework has emerged which now offers several conceptual propositions concerning how technological innovation effects market development $[8,33,34,43,44]$. The research presented in this paper does not attempt to test the evolutionary framework in its entirety, but it will empirically examine several proposi-

Research Policy 21 (1992) 13-25

North-Holland tions put forth by these researchers concerning industrial structure and diffusion of technology.

\section{Research approach}

The evolutionary framework suggests that technologies follow a trajectory of development $[32,34,43,44]$. Each trajectory marks a path of sustained technological innovation. As technologies progress along their trajectory of development, they become more complicated and require more resources to continue development $[8,32]$. This maturation process challenges organizations on both economic and engineering dimensions. Those organizations that are able to provide the necessary resources to meet each challenge will be better able of continuing to innovate.

In the evolutionary economic framework, radical and product innovation are considered critical to industrial structure [32,34]. Radical innovations in technology result in the creation of entirely new industries, such as occurred with the inventions of the jet aircraft or the transistor [9]. This type of innovation is beyond the scope of this paper. Product innovation is related to the improvement in capacity of products to fulfil certain functions and trace out a path or trajectory of a technology $[8,32]$. Sustained innovation, for purposes of this paper, is when a number of improvements in a product occurs sequentially and results in new generations of the product which have enhanced performance over previous generations of the product. This movement from one product generation to another, is responsible for changes in industrial structure which result in the evolution of 
an industry through a number of stages $[31,34,44]$. For purposes of this paper, then, innovation represents a change in technology which is manifested in the development of new products.

\section{Components of technologv}

In order to better understand how product innovation in a technology effects elements of industrial structure such as firm size and market concentration. it is important to explore what is meant by technology in greater detail. Technology represents the capability of the firm to confront uncertainty [40]. As noted above, from a firm's strategic perspective, technology is embodied in products. Clark [8] points out that products reflect the design and productive capabilities of firms. These design and productive capabilities can be viewed as composed of two stocks, one being a stock of capital and the other a stock of knowledge. The "stock of capital", is the physical/ material component of technology, most often embodied in laboratories and capital equipment. The "stock of knowledge" is most often embodied in people and procedures needed to generate technological innovation. For purposes of this research, additions to these two stocks will be termed "financial" and "informational" resources, respectively. Changes in the stock variables, represented by increases in the financial and information resources in a technology are necessary for innovation. This view of technological innovation is consistent with that of Nelson and Winter [32] and Sahal [43].

Organizational reactions to the changes in resource needs, resulting from the imperative of sustaned product innovation have direct consequences for firm size and industrial structure. Firms that are successful in innovating gain economic rents from producing products that competitors do not $[16,48]$. As a result, the innovative firm grows at the expense of the non-innovative firms. These firms should be better able to acquire the resources necessary to continue innovation and, as a result, large firms should be the innovators.

As industries have become increasingly global in competitive scope an important development in this argument concerning firm size and innovativeness has emerged [15,18]. Ferguson [15] has argued that large firms will be more innovative in global industries because these firms will be able to provide the resources necessary for innovation. Gilder [18] has argued that small firms are more able to innovate because these firms are not burdened by the "bureaucratic inertia" of large firms and are more adaptive to changes in markets.

Success of large versus small firms in innovating has a direct impact on industrial structure in that the success of large firms would increase the likelihood that markets would become more concentrated. Changes in industrial structure, such as firm size or market concentration, are important in that these will effect the diffusion of innovations [34]. As a technology matures, barriers to entry become great and fewer firms enter. resulting in a decreasing number of firms in the industry [31.34]. Firms that have already entered the industry as the prime movers in a technology are most likely to continue in the industry. Hence, both the number of firms and the continuity of the firms in an industry become constant or decrease as the technology matures.

To summarize, the evolutionary economic framework argues that continued product innovation requires increasing resources. This favors large firms and results in changes in industrial structure. Changes in industrial structure, as reflected in increases in firm size and market concentration levels should inhibit diffusion of innovation as reflected in the number of firms adopting an innovation and the continuity of innovating firms.

\section{Propositions}

Using the evolutionary economic framework described above as a base, several propositions will be derived that can be empirically tested. The first of these propositions is concerned with the changes in the resources needed as a technology undergoes a series of innovations, or sustained innovation. The second and third propositions are concerned with the impact of sustained innovation on firm size and market structure. The fourth and fifth are concerned with the impact of sustained innovation on diffusion.

Proposition One: As a technology undergoes sustained innovations, the level of informational and financial resources needed to continue innovation should increase. 
Propostion Two: As a technology undergoes sustained innovation, the size of the firms entcring first should increase.

Proposition Three: As a technology undergoes sustained innovation, the concentration of the industry should increase.

Proposition Four: As a technology undergoes sustained innovation, the maximum number of firms adopting the innovation should decrease.

Proposition Five: As a technology undergoes sustained innovation, the continuity of firms between innovations should increase.

\section{Methodology}

The above propositions were tested by examining the impact of technological innovation in the Dynamic Random Access Memory (DRAM) segment of the integrated circuit (IC) industry for the years 1974 to 1989. The DRAM segment was chosen because innovations in this device are crucial to developing the design and production technologies for all other integrated circuit devices [25]. It is also a technology where a number of product innovations have been generated over a period of years and as such has undergone sustained innovation. Consequently, the DRAM device lends itself to study of the impact of sustained innovation through product development on market structure.

Data for this study were collected from archival sources and during field trips in Japan and the United States. Japan and the United States were chosen because firms from both countries produce well over 90 percent of the DRAM devices sold in the world market [10]. Both the archival and interview data were collected between 1984 and 1990 .

It should be noted that only firms from the "merchant" portion of the DRAM market were used. These firms comprise about 92 percent of the entire production of DRAM devices. In 1990 this amounted to $\$ 7.15$ billion [25a]. Merchant firms are those that produce and sell the DRAM product to other firms. Firms, such as IBM, that produce the DRAM device, but do not sell it to other firms are known as "captive" suppliers and were excluded from this study. The total number of firms that were studied was 22 . This number varied somewhat throughout the time period of the study because some firms exited and other entered the DRAM segment of the integrated circuit industry.

\section{Measures}

\section{Sustained innovation}

A technological innovation was determined by a change in the capacity of the DRAM device to store information. This capacity was measured by the density or number of bits of information that can be stored in the memory device. Using this definition, there have been four product innovations, or changes in device type, in the DRAM during the period of study. The base is the $4 \mathrm{~K}$ DRAM and innovations occurred with the introduction of the $16 \mathrm{~K}$ DRAM, $64 \mathrm{~K}$ DRAM, $256 \mathrm{~K}$ DRAM. $1 \mathrm{Mb}$ DRAM and $4 \mathrm{Mb}$ DRAM. For this product. " $\mathrm{K}$ " represents 1000 bits, and "Mb" represents $1,000,000$ bits. From this progression of innovations, the DRAM product traces a technology trajectory from the $4 \mathrm{~K}$ through the $16 \mathrm{~K}, 64$ $\mathrm{K}, 256 \mathrm{~K}, 1 \mathrm{Mb}$ and the $4 \mathrm{Mb}$ devices.

\section{Financial resource needs}

The financial resources were measured by the initial average offering price of each device, and by the level of investment needed to enter the integrated circuit industry. Both of these measures are tied directly to improvements in DRAM product technology. As such these measures should provide a more accurate representation of the cost of innovating in this technology than would research and development or capitalization figures which represent expenditures for the industry as a whole.

\section{Informational resource needs}

Archival data on the use of informational resources is not available. Therefore, a surrogate measure was used to indicate the level of information resource use associated with each DRAM device. In the IC industry it is customary to circulate to potential customers, samples of integrated circuit devices that are new. These are 
samples of the prototype design of the new device or chip and are available in very limited quantity. There exists an interval of time between when the chips are first "sampled" and when they are available at "significant" production levels. "Sampling time" reflects the efforts necessary to "de-bug" the production of the initial product design based on customer feedback. Because of the relative simplicity of designing a new DRAM device compared to "ramping up" production, the sampling time is a good surrogate for information resource needed to move from prototype to a mass produced product.

To be conservative in this analysis, the "significant" level of production was chosen to be 40,000 units per quarter. This is a small quantity, and the importance of the demand factor is thus minimized. The difference between the quarter in which initial samples were sent to customers and the quarter when shipment was greater than 40,000 units was then calculated; this is called the sampling time. The average sampling time was determined for each DRAM device type by averaging the sampling time across all the firms that introduced the device. The differences in these averages were then calculated for all the firms in the DRAM market.

\section{Firm size}

A measure of firm size used by Nelson and Winter [34] in their study of innovation is market share. For this study, therefore, market share, as measured by sales revenue in the overall integrated circuit industry in the firm's home market, was used to determine the firm's rank. Use of the home market data was necessary because Japanese firms only became significant suppliers of DRAMs after the $64 \mathrm{~K}$ device was introduced. Therefore, only domestic sales figures were available for Japanese firms through the $64 \mathrm{~K}$ device. In order to maintain consistency, this method of calculating firm rank based on home market sales was applied throughout all the DRAM innovations. The rank of the firm in terms of home market share at the time it entered the market for each DRAM device type was used in the analysis. Again, it should be noted that only firms from the "merchant" portion of the DRAM market were used.

\section{Market structure}

The market structure was measured by a concentration ratio for firms producing the device. The degree of concentration was defined by the Herfindahl index [18a], the sum of the squared shares of each firm in the market. While only one measure of market structure was applied to the DRAM market, it is considered the best of the well known measures of concentration and theoretically superior to the four firm ratio which is often used because of ease of computation [18a]. Further, the Herfindahl index is a measure of market structure and not market performance and should therefore provide a clearer picture of the changes that occur with a change in technology $[21$, p. 51].

\section{Number and innovation continuty of firms}

The maximum number of firms that adopt an innovation is one measure of diffusion. This measure of diffusion was calculated for each type of device; that is, the $4 \mathrm{~K}$ through $4 \mathrm{Mb}$ markets. In the $4 \mathrm{Mb}$ market, the maximum number of firms was for the year 1988, the most recent time for which data were available.

With each innovation in the DRAM product firms that produced that device were noted. Innovation continuity of firms was defined as the period over which a firm was innovating, producing and selling each of the devices. For a firm to be considered a part of the DRAM market, it is not sufficient for the firm to be producing previous generations of DRAM devices. It must also be innovating and producing the most recent type of DRAM. The length of time that a firm was considered a part of the DRAM market was determined by the device type it entered on, such as $4 \mathrm{~K}, 16 \mathrm{~K}$ and so on, and if appropriate, the device type it exited on. Consequently, the continuity for a firm was measured by the firm's presence in a particular DRAM device type.

\section{Results}

Maturation in the DRAM product/technology

Within the evolutionary framework, it is important that the technology be mature, in order 
for it to exhibit the characteristics that are summarized in the propositions. The DRAM technology is maturing. Of the various integrated circuit devices produced by firms in the IC industry, it is one of the oldest. The very first DRAM was introduced in the early 1970s. While new devices are still being introduced, the rate of innovation, a measure of technological maturity, is decreasing.

While the IC technology has continued to progress through a number of innovations, the rate of innovation, as measured by the rate of density increase, has decreased since the 1960s. During the 1960 s the rate was about 100 percent per annum. Coincidental with the introduction of the first DRAM, this rate dropped to between 50 percent and 60 percent per annum in the 1970 s and is expected to decrease to 25 percent per annum in the late 1980s and 1990s [25]. Consequently, the DRAM has matured as it has progressed along its technological trajectory.

\section{Test of Proposition One: Financial resource needs}

As the DRAM device technology progressed along its technological trajectory and matured, the level of financial resources necessary for each device is expected to increase. This is reflected in table 1. In the table, the initial average selling price of each device is displayed. This price is the price at the time of introduction of the device, before learning curve economies within each device have set in. The price is a reflection of the capital and research and development expenses needed to bring the device into production.

A significant break occurs between the Large Scale Integration (LSI) production techniques (4 $\mathrm{K}$ and $16 \mathrm{~K}$ devices) and the Very Large Scale Integration (VLSI) production techniques $(64 \mathrm{~K}$,

Table 1

Inıtial average selling price for each DRAM device

\begin{tabular}{llll}
\hline Year & $\begin{array}{l}\text { DRAM } \\
\text { device }\end{array}$ & Technology & $\begin{array}{l}\text { Average selling } \\
\text { price (dollars in } \\
\text { year introduced) }\end{array}$ \\
\hline 1974 & $4 \mathrm{~K}$ & LSI & $\$ 40.00$ \\
1976 & $16 \mathrm{~K}$ & LSI & $\$ 60.00$ \\
1978 & $64 \mathrm{~K}$ & VLSI & $\$ 200.00$ \\
1980 & $256 \mathrm{~K}$ & VLSI & $\$ 200.00$ \\
1985 & $1 \mathrm{Mb}$ & VLSI & $\$ 150.00$ \\
1988 & $4 \mathrm{Mb}$ & ULSI & $\$ 452.00$ \\
\hline
\end{tabular}

Source: Dataquest [10].
Table 2

Estımated investment necessary for entry into the United States integrated circuit market

\begin{tabular}{ll}
\hline Year & $\begin{array}{l}\text { Investment } \\
\text { (million dollars } \\
\text { in year noted) }\end{array}$ \\
\hline 1957 & $0.1-0.35$ \\
1967 & 2.5 \\
1977 & 10 \\
1979 & 18.5 \\
1980 & 19.5 \\
1984 & 60 \\
1987 & 100 \\
1989 & 250 \\
1993 & 750 \\
\hline
\end{tabular}

Sources: Tilton [51a], ICE, varıous issues 1977-1989.

$256 \mathrm{~K}$, and $1 \mathrm{Mb}$ devices). The differences within the LSI and VLSI groups are not great, but between the LSI and VLSI groups a large difference is observed. While the initial price for the $1 \mathrm{Mb}$ device is lower than its VLSI companion devices, it is still more than double the price of the $16 \mathrm{~K}$ LSI device. Another significant break appears with the $4 \mathrm{Mb}$ device. This is the beginning of the Ultra Large Scale Integration (ULSI) devices, which includes the yet to be marketed $16 \mathrm{Mb}$ device, and the yet to be developed $64 \mathrm{Mb}$ device.

A similar pattern emerges from the financial investment needed to produce these devices. As noted in table 2 , the initial investment necessary for entry has risen from about 20 million dollars in 1980 to 60 million dollars in 1984 and to 100 million dollars in 1987. In 1989 the cost of establishing a state-of-the-art fabrication facility was estimated to be $\$ 250$ million and the projections are that by 1993 it will cost over $\$ 750$ million. It is evident from these two tables that the financial resources needed for continued innovation in the DRAM segment of the integrated circuit industry is increasing.

Test of Proposition One: Information resource needs

As the DRAM device technology has matured, information resources also increased. The division between LSI and VLSI that was seen with the financial resources, was used in the analyses of the information resources. As seen in table 3, the average sampling times are increasing as the innovations move from the LSI to the VLSI devices. 
Table 3

Mean sampling tıme. ANOVA and T-test for informational resources for the DRAM market

\begin{tabular}{|c|c|c|c|c|c|c|}
\hline \multicolumn{7}{|l|}{ Estımate of means } \\
\hline $\begin{array}{l}\text { Sampling tıme } \\
\text { (quarter years) }\end{array}$ & & $\begin{array}{l}\text { Device o } \\
\text { LSI } \\
150\end{array}$ & $\begin{array}{l}\text { VLSI } \\
396\end{array}$ & & & \\
\hline \multicolumn{7}{|c|}{ Analyss of variance } \\
\hline Source & $\begin{array}{l}\text { Degrees } \\
\text { of } \\
\text { freedom }\end{array}$ & $\begin{array}{l}\text { Sum of } \\
\text { squares }\end{array}$ & $\begin{array}{l}\text { Mean } \\
\text { squares }\end{array}$ & $F$-value & Probability & \\
\hline Device category & 1 & 141.466 & 141.466 & 39.076 & 0.000 & \\
\hline \multicolumn{7}{|l|}{ Estumate of means } \\
\hline $\begin{array}{l}\text { Sampling tıme } \\
\text { (quarter years) }\end{array}$ & & $\begin{array}{l}4 \mathrm{~K} \\
121\end{array}$ & $\begin{array}{l}16 \mathrm{~K} \\
1.78\end{array}$ & $\begin{array}{l}64 K \\
417\end{array}$ & $\begin{array}{l}256 \mathrm{~K} \\
356\end{array}$ & $\begin{array}{l}1 \mathrm{Mb} \\
4.27\end{array}$ \\
\hline \multicolumn{7}{|c|}{ Analysis of variance } \\
\hline Source & $\begin{array}{l}\text { Degrees } \\
\text { of } \\
\text { freedom }\end{array}$ & $\begin{array}{l}\text { Sum of } \\
\text { squares }\end{array}$ & $\begin{array}{l}\text { Mean } \\
\text { squares }\end{array}$ & $F$-value & Probability & \\
\hline Device type & 4 & 147.252 & 36.813 & 9.323 & 0.000 & \\
\hline
\end{tabular}

AIl ANOVA indicated that the difference in means was statistically significant.

This analysis was repeated for each of the device types, $4 \mathrm{~K}, 16 \mathrm{~K}, 64 \mathrm{~K}, 256 \mathrm{~K}$ and $1 \mathrm{Mb}$ DRAM. This was done in order to provide a more detailed examination of the changes in information resources. Again, the average sampling time increases from the $4 \mathrm{~K}$ to the $64 \mathrm{~K}$. Although there is a decline with the $256 \mathrm{~K}$ device the upward trend continues with the $1 \mathrm{Mb}$ device. An analysis of variance test applied to the data for the $4 \mathrm{~K}$ through the $1 \mathrm{Mb}$ device shows similar results to those found in testing the differences between LSI and VLSI categories; that is, the differences in the mean sampling time are statistically significant. Having examined the relationship between both resource needs and innovation, and having shown that these increase as predicted by Proposition One, the effect of these changes on market structure and firm size will now be explored.

\section{Test of Proposillon Two: Firm size}

The data on firm size is presented in table 4 . The first three entrants into each device market is displayed in the table. In the case of ties, where more than one firm introduced the device at the same time, they are grouped together and share the same entrant position.
From the table, it can be seen that relatively small firms dominated in the LSI era, $4 \mathrm{~K}$ and 16 $\mathrm{K}$ DRAM devices. The first firms to enter, or "prime movers", were not in the largest market

Table 4

Comparison of entry order with firm size and entry date for United States and Japanese firms in the DRAM market a

\begin{tabular}{|c|c|c|c|}
\hline & First entrant & Second entrant & Thurd entrant \\
\hline $4 \mathrm{~K}$ & $\begin{array}{l}\text { Intel (5) } \\
\mathrm{TI}(1)\end{array}$ & Mostek (10) & NEC (3) \\
\hline $16 \mathrm{~K}$ & $\begin{array}{l}\text { Intel (4) } \\
\text { Mostek (9) }\end{array}$ & $\begin{array}{l}\text { TI (1) } \\
\text { Fujitsu (7) }\end{array}$ & NEC (3) \\
\hline $64 \mathrm{~K}$ & Fujitsu (4) & TI (1) & Motorola (3) \\
\hline $256 \mathrm{~K}$ & Hitachı (2) & $\begin{array}{l}\text { AT\&T (N/A) } \\
\text { Fujıtsu (4) } \\
\text { Toshıba (3) } \\
\text { Okı (8) }\end{array}$ & NEC (1) \\
\hline $1 \mathrm{Mh}$ & $\begin{array}{l}\text { AT\&T (N/A) } \\
\text { Toshiba (4) } \\
\text { Hitachi (2) }\end{array}$ & $\begin{array}{l}\text { Fujitsu (3) } \\
\text { NEC (1) }\end{array}$ & $\mathrm{TI}(1)$ \\
\hline $4 \mathrm{Mb}$ & $\begin{array}{l}\text { Hitachı (3) } \\
\text { NEC (1) } \\
\text { Toshıba (2) }\end{array}$ & $\begin{array}{l}\text { Fujıtsu (5) } \\
\text { Mitsubishı (7) } \\
\text { Oki (17) } \\
\text { TI (2) }\end{array}$ & $N / A$ \\
\hline
\end{tabular}

"Figures in parentheses represent the rank of the firm in terms of home country market share

Sources: Dataquest [9a]: Integrated Circuit Engineerıng. 19741989. 
share positions. It should be noted that the firms innovating in the LSI period were entrepreneurial start ups. As seen in the table, two U.S. firms, Intel and Mostek were archetypical entrepreneurial start up firms at the time of the introduction of those early devices.

From the table it can also be observed that firms which were "prime movers", in one product generation, such as the $16 \mathrm{~K}$ DRAM device type, were not able to translate this advantage to succeeding generations of the DRAM, such as the 64 $\mathrm{K}$ and $256 \mathrm{~K}$. First to market with one new product innovation does not guarantee first to market status in succeeding product generations. Further, as the DRAM product/technology matured, and entered the VLSI era, the $64 \mathrm{~K}, 256 \mathrm{~K}$ and $1 \mathrm{Mb}$ devices, a major change can be observed from the table.

As predicted in Proposition Two, large firms did begin to dominate the market. Both Intel and Mostek had dropped out of the DRAM product market completely by the time of the introduction of the $1 \mathrm{Mb}$ DRAM device. The trend began in the $64 \mathrm{~K}$ device market with Fujitsu, Texas Instruments and Motorola being the innovators. This trend becomes more pronounced in the $256 \mathrm{~K}$ and $1 \mathrm{Mb}$ markets where large firms have clearly established their innovative role. It is continuing with the $4 \mathrm{Mb}$ device market. However, one firm, Oki, is quite small in market share terms relative to other Japanese IC producers. Overall this trend is in accord with Proposition Two and tends to lend credence to the argument that large firms have an advantage in innovation in response to increasing resource needs. The impact of the increase in firm size on market structure will be examined in the next section.

Test of Proposition Three: Market structure and the diffusion process

The Herfindahl index was computed for the overall sample and for each quarter for which data was available. The time interval was from the first quarter of 1974 until the last quarter of 1988. The Herfindahl index for the DRAM market is displayed in fig. 1. The most striking feature of the figure is that the market concentration decreases over time. This is not in accord with Proposition Three. It is also a counter-intuitive result, given the increasing firm size noted in the above section.

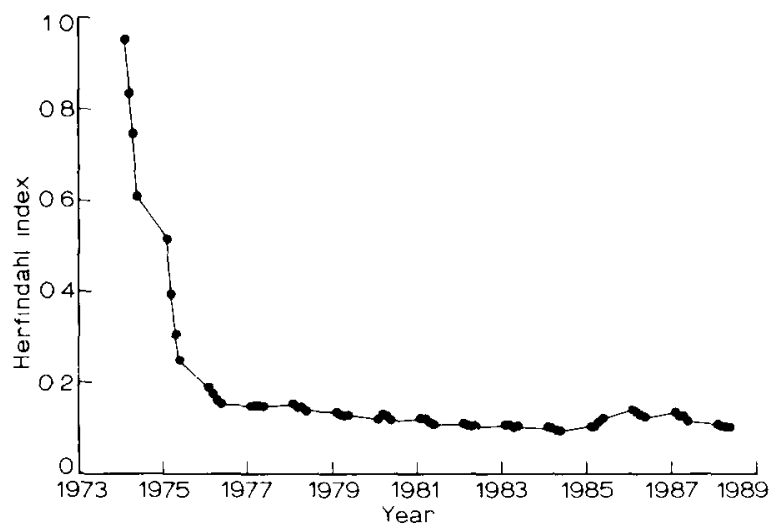

F1g. 1. Level of concentration for US and Japanese producers of DRAM devices as measured by the Herfindahl index $1973-$ 1988.

This contradiction between larger firms in a less concentrated market will be examined in a later section.

Test of Proposition Four: Maxımum number of firms in each device market

Data on the maximum number of firms in each device market is presented in table 5. The data presented is for the $4 \mathrm{~K}, 16 \mathrm{~K}, 64 \mathrm{~K}, 256 \mathrm{~K}$ devices and $1 \mathrm{Mb}$ devices. The $4 \mathrm{Mb}$ device is included, but results for this device are still considered preliminary because it is still in the early years of introduction.

As is evident from the table, the number of firms for the total DRAM device market became constant at seventeen firms after the $16 \mathrm{~K}$ device and continued at this number through the $256 \mathrm{~K}$ device. The number of firms that have entered the $1 \mathrm{Mb}$ device market is fourteen as of 1989. Thus overall, the pool of potential adopters is stabilizing. Further, it is stabilizing at a number that is

Table 5

Maximum number of firms participating in each DRAM market

\begin{tabular}{lllc}
\hline Device & $\begin{array}{l}\text { Total } \\
\text { furms }\end{array}$ & $\begin{array}{l}\text { Unted States } \\
\text { firms }\end{array}$ & $\begin{array}{l}\text { Japanese } \\
\text { firms }\end{array}$ \\
\hline $4 \mathrm{~K}$ & 13 & 10 & 3 \\
$16 \mathrm{~K}$ & 17 & 11 & 6 \\
$64 \mathrm{~K}$ & 17 & 9 & 8 \\
$256 \mathrm{~K}$ & 17 & 9 & 8 \\
$1 \mathrm{Mb}$ & 14 & 4 & 10 \\
\hline
\end{tabular}

Source: Dataquest [10]. 
far smaller than the total number of firms that are in the integrated circuit industry.

Part of the explanation for this limited diffusion of the DRAM technology to other firms in the IC industry can be found in the fact that as the DRAM technology matured, firms that were unable to acquire the necessary resources to commit to DRAM innovation. did not enter. Firms which had entered but could not maintain the necessary resource commitment for further innovation, exited from the DRAM segment of the IC industry. Consequently. the number of firms innovating and producing DRAM devices has stabilized and appears to be falling with the $1 \mathrm{Mb}$ device. Thus. Proposition Four is supported by the data presented.

These findings offer only part of the picture of the diffusion process, however. In order to gain a better understanding of the dynamics of adoption it is important to examine the continuity of the firms.
Test of Propositton Five: Contınuty of firms between device innovations

Information concerning innovation continuity is supplied in fig. 2. The existence of strong continuity among the firms would indicate that barriers to entry exist through first mover advantages. These barriers would slow the diffusion process. From the figure it is evident that both entry as well as exit have occurred throughout the life cycle of the DRAM technology. Ten firms have entered the merchant end of the DRAM IC industry. Nine firms have exited from the merchant IC industry. Two firms have exited and re-entered. These are indicated by the broken lines for Intel and Motorola. ATT is still producing the $1 \mathrm{Mb}$ DRAM but is not selling it in the merchant market.

Additional firms have entered with each new device type. Three firms entered in the $16 \mathrm{~K}$, two in the $64 \mathrm{~K}$, three in the $256 \mathrm{~K}$ and two in the 1 $\mathrm{Mb}$ device market. It should be noted that in the

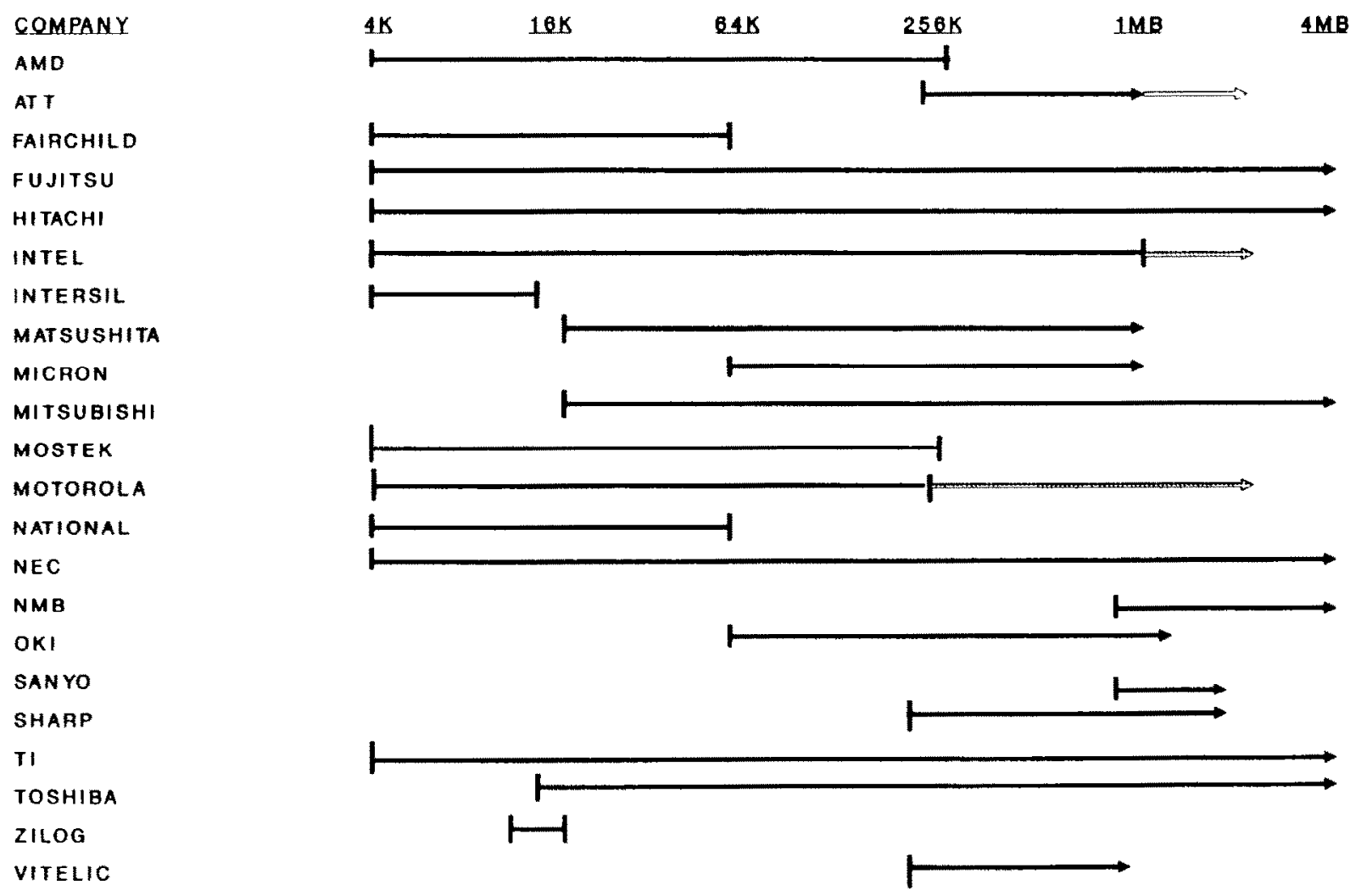

Fig. 2. Contimuity among firms producing DRAM devices. 
$64 \mathrm{~K}, 256 \mathrm{~K}$ and $1 \mathrm{Mb}$ devices one of the entering firms, has been an entrepreneurial start up firm. Micron, in the $64 \mathrm{~K}$, Vitelic in the $256 \mathrm{~K}$ and a venture start up, albeit a well financed venture firm from Japan, NMB, in the $1 \mathrm{Mb}$ device have each innovated these VLSI devices. As of the first quarter of 1990, no new entrants have emerged in the $4 \mathrm{Mb}$ device market. The existence of entry into the DRAM technology is not in accord with the strict technological primacy of the evolutionary economists. However, the findings do provide some insight into the decrease in market concentration. As new firms enter with each innovation in the DRAM technology, the market is divided among more firms.

To summarize the findings thus far, the evolutionary economic framework has received partial support from the data presented and analyses performed. Both the information and financial resources were found to increase with succeeding innovations in accordance with Proposition One. Consequently, as predicted by Proposition Two the size of the innovating firms increased with the movement from LSI to VLSI. However, the level of market concentration has continually decreased contrary to Proposition Three. Thus, the findings on industrial structure are mixed. Consequently, the findings concerning the diffusion of innovation are also mixed. From Proposition Four, the maximum number of firms was shown to increase from the $4 \mathrm{~K}$ to $16 \mathrm{~K}$ and then to stabilize for the $64 \mathrm{~K}$ and $256 \mathrm{~K}$ product markets. This number has declined in the $1 \mathrm{Mb}$ product market. As the DRAM technology has undergone continuous innovation in its products, the industry is coalescing around a core group of companies in accordance with Proposition Five, but barriers to entry and exit are not yet strong enough to preclude movement into or out of the DRAM market.

\section{Further analysis of demand factors}

The mixed findings on industrial structure raise some questions concerning the extent to which the DRAM market structure is driven strictly by technological change in the DRAM technology itself. Why are firms entering the DRAM product market. when the resources required to continue innovation increase with each new product introduction? Why has the market concentration con-

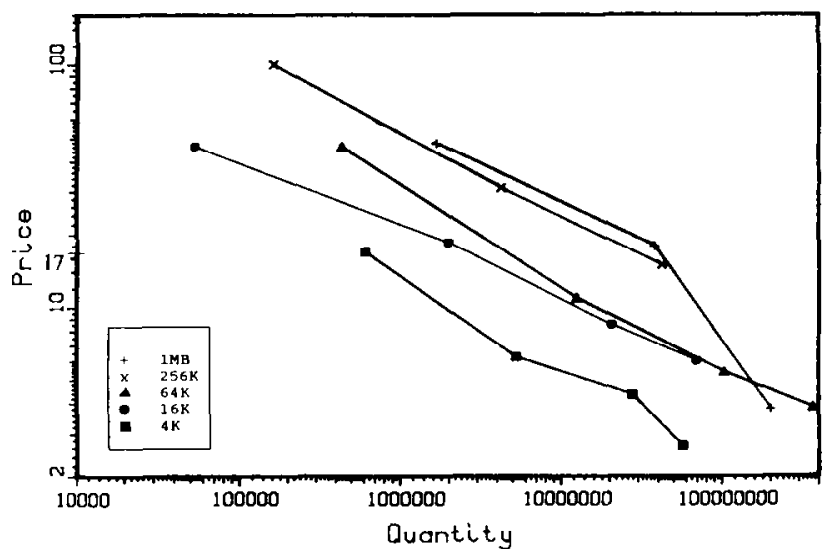

Fig. 3. Price and quantity shift under sustained innovation in the DRAM market.

tinued to decline throughout the life of the DRAM technology, even though the maximum number of firms has dropped in the $1 \mathrm{Mb}$ device market? To answer these questions, additional analyses were performed on changes in demand for the DRAM device.

DRAM market expansion and technological sophistication

One possible explanation for the conflicting results between firm size and market concentration would be that the demand for the product has increased over time. Firms could become larger without the market becoming more concentrated. Measuring the demand curve of a product is empirically very difficult. However, a useful surrogate does exist. From the data collected for each device, the price and quantity combinations are known. If the quantity from device to device can be shown to increase with the price held constant, then the market can be shown to be expanding. This data is presented in fig. 3 .

From the figure it is readily apparent that the market is expanding. since the demand curves shift outward with each device type. In order to understand the precise magnitude of these shift it is useful to compare price and quantity combinations. The price and quantity combinations for each device are not perfectly matched, but comparisons can be made.

One price will be chosen and comparisons of the quantities demanded at that price will be enumerated. A price of $\$ 17.00$ per unit is the best 
candidate for comparisons across all the device types. For the $4 \mathrm{~K}$ device, the quantity demanded in the market at $\$ 17.00$ per unit was 615,000 . The quantity increased to $2,008,000$ for the $16 \mathrm{~K}$ and to $12,631,000$ for the $64 \mathrm{~K}$. There were similar increases for the $256 \mathrm{~K}$ and $1 \mathrm{Mb}$ devices with $37,980,000$ and $211,633,000$ DRAM units demanded at the chosen price. Thus, shifts of the supply and demands curves are occurring as well as movement along them. Hence, it is possible for firms to grow larger without pushing other firms out of the market since the market is expanding.

This expansion in the market is related to the increasing capacity of the DRAM device for memory storage. This has made each succeeding innovation in the DRAM technology more appealing to users of IC memory technology. As a result, the number of types of applications have increased, causing, in turn, an increase in the number of DRAM users.

As can be seen in table 6, with each new DRAM product innovation the number of applications has increased. Applications for the DRAM began primarily with mainframe computers. This application has continued to expand as the types of computers, such as personal computers, have grown in number and these computers have been used in a wider variety of industrial and commerclal settings. Further, there is a growing number of consumer applications, such as VCRs and the development of HDTV. This shift in applications for the DRAM has had broad implications for the producers of the DRAM device. It is the technological improvements in the DRAM device which have caused the increase in the number of applications, and this, in turn has resulted in the shift outward of the demand curves for each DRAM device type.

\section{Discussion}

\section{Implications for firms}

From the above analyses it can be seen that sustained innovation does help to establish the strategic environment in which firms must compete. Three basic findings from this study provide an initial evaluation of the usefulness of the evolutionary framework in providing insights into how sustained innovation effects the strategic environ-
Table 6

\begin{tabular}{|c|c|}
\hline $\begin{array}{l}\text { DRAM } \\
\text { Device type }\end{array}$ & $\begin{array}{l}\text { RAM } \\
\text { use }\end{array}$ \\
\hline $1 \mathrm{~K}$ & Maınframe \\
\hline $4 \mathrm{~K}$ & $\begin{array}{l}\text { Mainframe } \\
\text { Minicomputer }\end{array}$ \\
\hline $16 \mathrm{~K}$ & $\begin{array}{l}\text { Mainframe } \\
\text { Mınicomputer } \\
\text { Graphics }\end{array}$ \\
\hline $64 \mathrm{~K}$ & $\begin{array}{l}\text { Mainframe } \\
\text { Mınicomputer } \\
\text { Personal computer } \\
\text { Graphics }\end{array}$ \\
\hline $256 \mathrm{~K} / 1 \mathrm{Mb}$ & $\begin{array}{l}\text { Maınframe } \\
\text { Mınıcomputer } \\
\text { Small business computer } \\
\text { Portable computer } \\
\text { Personal computer } \\
\text { Workstation } \\
\text { CAD/CAM } \\
\text { Robotics } \\
\text { Graphics }\end{array}$ \\
\hline $4 \mathrm{Mb}$ & $\begin{array}{l}\text { Mainframe } \\
\text { Minicomputer } \\
\text { Home workstatıons } \\
\text { Small business computer } \\
\text { Portable computer } \\
\text { Personal computer } \\
\text { Laptop computer } \\
\text { Workstation } \\
\text { CAD/CAM/CIM } \\
\text { Roboncs } \\
\text { HDTV } \\
\text { Graphics }\end{array}$ \\
\hline
\end{tabular}

ment. First, as suggested by the evolutionary school of thought, the need for resources for innovation does increase as the technology matures. This could account for the emergence of large firms as innovators in the latter, VLSI portion of the DRAM device trajectory. The effect of this increase in resources is moderated by the growth of demand for the product, however. Growth in the demand for the DRAM was tied to the increasing variety of uses for the DRAM, which in turn is tied to the increasing memory storage capacity of the DRAM. It was this rapid growth in demand which allowed for the entry of new firms, and as a result the concentration ratio of the DRAM segment has decreased over time. It appears that sustained technological innovation 
can be both a blessing and a curse for firms. At once increasing both the requisite resource level needed to innovate a product and the demand for each product innovation.

Second, first movers did not necessarily have the advantage that is suggested by the evolutionary school of thought. While first mover advantages were enjoyed within each DRAM product innovation, that was not the case between the innovations. Each new innovation provided a "window of opportunity" for a firm lagging in the current product generation to attempt to gain on the leading firm and overtake it with the innovation of the next product generation. Although some form of Schumpeterian competition was found to occur, the monopoly rents derived from such competition were low across the DRAM product innovation categories. Under conditions of sustained innovation in the DRAM technology, there was a crowding of firms into the first three entry positions. This suggests that the usual definition of "prime mover" may be too narrow if it applies only to the first firm to enter with an innovation.

Both the first and second findings have implications for the debate concerning firm size and innovativeness most recently raised by Ferguson and Gilder [15,18]. Although large firms have come to dominate the DRAM segment of the IC industry, many of these firms have grown large because they have stayed in the DRAM segment and continued to innovate. Also, firms are continuing to enter the DRAM segment; two were entrepreneurial start up firms from the U.S. and one from Japan. All entered during the VLSI era, which was shown to require more resources than the LSI era for innovation. Further, while large firms have become the innovators, they were not able to maintain their prime mover lead from innovation to innovation. These findings tend to present a more complicated picture of firm size and innovativeness than presented either by Ferguson or Gilder.

The third finding concerns the effect of sustained innovation on diffusion. The diffusion curve for the DRAM technology did not follow the smooth S-curve pattern. In spite of expanding demand for the DRAM product, the number of firms adopting the various DRAM innovations was far short of the total number of firms in the integrated circuit industry. The increasing techno- logical cost of entry as exhibited by increases in the financial and information resources limited the number of potential adopters of the DRAM. The rate of adoption did not follow the standard sigmoidal pattern of increasing up to the 50 percent point and then decreasing.

As seen from fig. 2, even viewing diffusion from the perspective of those firms most likely to "adopt" a new DRAM innovation - that is, those firms that had produced the previous innovation many failed to do so. It even appears that a "shake out" occurred within the $1 \mathrm{Mb}$ product category. While the demand curve has continued to shift outward, a recession that occurred in the IC industry at the same time as the introduction of the $1 \mathrm{Mb}$ device, caused a number of DRAM producers from the U.S. side to exit. Although some of these firms have re-entered under various forms of licensing agreements from Japanese firms, in terms of the firms producing the DRAM innovations, the results favor the interpretation that the diffusion curve has not followed an S-shaped pattern.

In summary, sustained technological innovation was found to result in increased financial and information resources. Large firms were more able to sustain the innovative momentum necessary to remain in the DRAM market, but not at the total exclusion of small firms. The results concerning sustained technological innovation and market structure were more complicated. Increases or decreases in demand were also found to effect both firm entry, exit and market concentration. From the findings derived from the DRAM industry, it would appear that demand factors cannot be ignored even in an industry characterized by sustained technological innovation.

\section{Future research}

This study is not a complete test of the evolutionary framework, but it does offer some insights into the evolutionary economic framework based on empirically derived data. These insights are particularly important as firms in industries other than the integrated circuit industry attempt to use fast product development cycles as a competitive strategy. Clarification of first mover advantages when demand and technology factors are interacting needs further research. Research into this area will also help to explain more fully the debate 
between those favoring large firms and those favoring small firms as innovators.

Since this study examined an important product, the DRAM, it provides a base for further empirical examination of the interaction of demand and technology factors in an industrial setting. It points to the importance of and need for more longitudinal or time series studies of products and technologies in other industrial settings. Hence, another fruitful area for future research would be to examine the evolutionary framework in other industries that are characterized by sustained product innovation. Such work would also lead to a more comprehensive and complete test of the evolutionary economic framework.

\section{References}

[1] William J. Abernathy and James M. Utterback, Patterns of Industrial Innovation, in: A.L Tushman and W.L. Moore (eds), Readings in the Management of Innovation (Pitman Publishıng, Inc. Marshfield, MA, 1982) pp. 97-108

[?] Willam I. Ahernathy and Kenneth Wayne, Limits of the Learnıng Curve, in: M.L. Tushman and W.L. Moore (eds), Readings in the Management of Innovation (Pitman Publishıng, Inc., Marshficld, MA, 1982) pp. 109-121.

[3] Robert U. Ayers, The Next Industrial Revolution Reveing Industry Through Innovation (Ballinger Publishing Co.. Cambridge, MA. 1984).

[4] B.A. Asia, Consulting Group. The Japanese Semiconductor Industry 1981/1982 (B.A. As1a Ltd., Hong Kong. 1982)

[5] Clifford Barney, Winds of Change Sweep the Industry, Electronics 60 (7) (April 2, 1987) 62-67.

[6] Frederick Betz, Managing Technologv" Competing Through New Ventures. Innovaton and Corporate Research (Prentice-Hall, Inc., Englewood Cliffs, NI, 1987).

[7] Rıchard E. Caves and Masu Uekusa, Industrial Organization in Japan (The Brookıngs Institution, Washıngton. D C.. 1976).

[8] Kim B. Clark, The Interaction of Design Hierarchies and Market Concepts in Technological Evolution. Research Policy 14 (1985) 235-251

[9] Arnold C Cooper and Dan Schendel, Strategic Responses to Technology Threats, Business Horizons (February 1976) 61-69

[9a] Dataquest, Inc., MOS Static and Dynamic RAM Shipments, Second Half 1983 - Year-end Review (Dataquest Inc., San José, Ca, 15 May 1984).

[10] Dataquest, Inc., MOS Static and Dynamic RAM Shipments. Second Half 1989 - Year-end Review (Dataquest Inc., San José, CA, 15 May 1989)

[11] Denkı Kıki Shijo Chosa Kaihen, Denshl Shyo Yoran 1980 (Kagaku Shinbun Sha, Tokyo, Japan. 1980).
[12] Dodwell Marketing Consultants, Industrial Groupings in Japan 1980/1987 (Dodwell Marketıng Consultants, Tokyo, Japan, 1986).

[13] M.H. Eklund and W.I. Strauss (eds), Status 1982 A Report on the Integrated Circut Industry. (Integrated Circutt Engineering Corporation, Scottsdale, AZ, 1982)

[14] M H Eklund and W.I. Strauss (eds). Status 1984 A Report on the Integrated Curcult Industry' (Integrated Circuit Engineering Corporation, Scottsdale, AZ, 1984)

[15] Charles H. Ferguson. From the People Who Brought You Voodoo Economics, Harvard Business Review (May-June 1988) 55-62.

[16] Therese M. Flaherty, Market Share, Technology Leadership and Competition in International Semiconductor Markets, in: Richard S Rosenbloom (ed.). Research on Technological Innovation. Management and Policy Vol 1 (JAI Press, Inc., London, 1983).

[17] Fortune. The 500 Largest Industrial Corporations, Fortune (New York. 28 April, 1986)

[18] George Gilder, The Revitalization of Everything The Law of the Microcosm. Harvard Business Reven (March-April 1988) 49-61

[18a] John C Hanse. The Measurement of Concentrated Industrial Structure and the Size Distribution of Firms. Annals of Ecnomic and Social Measurement 6(1) (Winter 1977). 73-107

[19] Nico Hazewindus with John Tooker, The US Microelectronics Industry. Technical Change. Industry Growth and Social Impact (Pergamon Press, New York, 1982).

[20] Japan Flectronics Industry Association. Shusekt Kato Gudo Bukku (Japan Electronics Industry Association, 1984).

[21] Morton I. Kamicn and Nancy L. Schwartz, Market Structure and Innocation (Cambridge University Press, Cambridge, U.K., 1982).

[21a] Burton H. Klein, Prices, Wages, and Business Cycles. A Dynamic Theory (Pergamon, New York, 1984).

[22] Sven B. Lundstedt and E. William Colglazier, Jr. Managing Innotation: The Social Dimension of Creatulty, Invention and Technology (Pergamon Press, New York. 1982).

[23] William J. McClean (ed.), Status 1985: A Report on the Integrated Circult Industry (Integrated Circult Engineering Corp., Scottsdale, AZ, 1985)

[24] William J. McClean (ed.), Status 1986 A Report on the Integrated Circult Industry (Integrated Circult Engineering Corp., Scottsdale, AZ, 1986)

[25] William J. McClean (ed.), Status 1989. A Report on the Integrated Circult Industry (Integrated Circuit Engineering Corp., Scottsdale, AZ, 1989).

[25a] William J. McClean (ed.), Status 1990. A Report on the Intergrated Circuit Industry (Intergated Circuit Engineering Corp.. Scottsdale, AZ, 1990).

[26] Denis J. Mc Greıvy and Kenneth A. Pickar, VLSI Technologies Through the 80's and Beyond (Institute of Electrical and Electronic Engineers, Inc., New York, 1982).

[27] David T. Methé, Technology, Transaction Costs, and the Diffusion of Innovation. The Evolution of the United States and Japanese DRAM Integrated Circult Industries (University of California, Irvine, unpublished dissertation, 1985). 
[28] David T. Methé, Innovation, Institutions and Strategies The Evolution of the United States and Japanese Firms in the DRAM Industry. Strategic Management Society, Sixth Annual Conference, Singapore, October, 1986.

[29] Ashoka Mody and David Wheeler, Technological Evolution of the Semiconductor Industry, Technological Forecasting and Social Change 30 (1986) 197-205

[30] William L. Moore and Michael L. Tushman, Managing Over the Product Life Cycle, in: Michael L. Tushman and William L. Moore (eds), Readings in the Management of Innocation (Pitman Publishing, Inc. Marshfield, MA, 1982).

[31] D.C. Mueller and J.E. Tilton, Research and Development Costs as Barriers to Entry, Canadian Journal of Economics (4) (November 1969) 570-579.

[32] Richard R. Nelson and Sidney G. Winter. In Search of Useful Theory of Innovation, Research Polcy 6 (1977) $36-76$.

[33] Ruchard R. Nelson and Sidney G. Winter, Forces Generating and Limiting Concentration Under Schumpeterian Competition, Bell Journal of Economics (2) (Autumn 1978) 524-548.

[34] Richard R. Nelson and Sidney G. Winter, An Evoluttonary Theory of Economic Change (The Belknap Press of the Harvard University Press, Cambridge, MA, 1982).

[35] Nihon Karhatsu Ginko, Chosa Bu, IC Sangyo '80 Nenda1 No Tembo Chosa (January, 1984).

[36] Nomura Research Institute, SEMI Japanese Semiconductor Industry Report (Semiconductor Equipment and Matenals Instıtute. Mountain View. CA. 1983).

[37] Ikujıro Nonaka, Tadao Kagono and Shion Sakamoto, Evolutionary Strategy and Structure: A New Perspective on Japanese Management. Discussion Parer No. 111, Institute of Business Research, Hitotsubashı University, March, 1983.

[38] Alman Phıllıss, Technology and Market Structure: Study of the Aircraft Industry (D.C. Heath and Company, Lexington, MA, 1971)

[39] Michael E. Porter, Competitive Strategv: Techniques for Analving Industries and Competitors (The Free Press, New York, 1980).

[40] Everett M. Rogers, Diffuston of Innovations. Third Ed. (The Free Press, New York, 1983).

[41] Richard S. Rosenbloom (ed.), Research on Technological Innotation Management and Policy. Vol. 1 (JAI Press, Inc., London, 1983)

[42] Vernon W. Ruttan and Yujıro Hayami, Toward a Theory of Induced Institutional Innovation, Journal of Development Studies 20 (4) (July 1984) 203-223.
[43] Devendra Sahal, A Theory of Evolution of Technology, International Journal of Systems Science 10 (3) (1979) 259-274.

[44] Devendra Sahal, Patterns of Technological Innovation (Addison-Wesley Publıshing Co., Inc., Reading. MA. 1981).

[45] Masaru Saito, Internal Transfer and Technology Transfer From Abroad: Japanese Experience. Workshop on Technology Transfer and Plan, Kuala Lumpur, December, 1983.

[46] David E. Sanger, Trying to Regain the Market in Chips, The New York Times (8 March 1987) E 7.

[47] Brenton R. Schlender and Stephen Kreider Yoder, Falling Chips: U.S.-Japanese Accord on Semiconductors Has an Impact, but Not the One That Was Hoped For, The Wall Street Journal (12 February 1987) pp. 10+

[48] Joseph, A. Schumpeter, Business Cycles: A Theoretical, Historical and Statistical Analysis of the Capttalist Process (McGraw-Hill, New York, 1939).

[49] Francis C. Spital, Gaining Market Share Advantage in the Semiconductor Industry by Lead Time in Innovation, in: Richard S. Rosenbloom (ed.), Research on Technological Innovation, Management and Pohcy. Vol. 1 (JAI Press, Inc., London, 1983).

[50] David J. Teece, Economics of Scope and the Scope of the Enterprise, The Journal of Economic Behavior and Organization 30 (2 December 1981) 173-200.

[51] Hans B. Thorell,, Networks: Between Markets and Hierarchies, Strategıc Management Journal (JanuaryFebruary 1986) 37-51

[51a] John E. Tilton, International Diffusion of Technology: The Case of Semiconductors (The Brookings Institution, Washington D.C., 1971).

[52] Michael L. Tushman and William L. Moore, Readings in the Management of Innovation (Pitman Publishing. Inc., Marshfield, MA, 1982).

[53] Eric von Hippel. The Dominant Role of Users in the Scientufic Instrument Innovation Process, Research Policy 5 (1976) 212-239.

[54] Robert W. Wilson, Peter K. Ashton and Thomas P Egan, Innovation Compettion, and Government Poltcy in the Semiconductor Industry (D.C. Heath and Company, Lexington, MA. 1980)

[55] Yano Keizai Kenkyu Jo, 1984 Handota Sangyo no Chukı Juyo Tembo. (Yano Keızai Kenkyu Jo, Tokyo, Japan, 1984). 